\title{
Design and synthesis of novel benzothiophene and dibenzothiophene derivatives and their biological properties
}

\author{
Arif Kivrak ${ }^{1}$, Muheb A. S. Algsoa ${ }^{1}$, Can Yilmaz², Metin Konus ${ }^{2}$, Aslihan Kurt-Kizildogan ${ }^{3}$ \\ ${ }^{I}$ Deparment of Chemistry, Van Yuzuncu Yil University, Turkey, ${ }^{2}$ Department of Molecular Biology and Genetics, Van \\ Yuzuncu Yil University, Van, Turkey, ${ }^{3}$ Department of Agricultural Biotechnology, Faculty of Agriculture, Ondokuz \\ May\&\#305; University, Samsun, Turkey
}

Heteroaromatics and their derivatives have very critical roles in discovery and development of new drug candidates due to their biological and pharmacological properties (1). Benzothiophenes, dibenzothiophenes and thiophenes are the well known member of heteroaromatic compounds and used in pharmaceuticals such as Raloxifene (2) Zileuton (3) Sertaconazole (4) They have been also used as anti-parasitic, anti-bacterial, anti-cancer, anti-fungal, anti-inflammatory and anti-oxidant drugs (5). In the present study, novel benzothiophene and dibenzothiophene derivatives were synthesized regioselectively by using coupling reactions and electrophilic cyclization reactions. In addition, antimicrobial properties of isolated compounds were tested against indicator microorganisms, and antioxidant capacity of benzothiophenes were investigated. The detail results will be presented at meeting.

(1) (a) Brasholz, M.; Reissig, H. U.; Zimmer, R. Accounts of Chemical Research 2009, 42, 45. (B) Kivrak, A.; Larock, R. C. Journal of Organic Chemistry 2010, 75, 7381.

2. Meixner, C. N.; Aref, M. W.; Gupta, A.; McNerny, E. M. B.; Brown, D.; Wallace, J. M.; Allen, M. R. Calcified Tissue International 2017, 101, 75.

(3) Sarret, C.; Pichard, S.; Afenjar, A.; Boespflug-Tanguy, O. Neuropediatrics 2017, 48, 205.

(4) Croxtall, J. D.; Plosker, G. L. Drugs 2009, 69, 339.

(5) (a) Coa, J. C.; Castrillon, W.; Cardona, W.; Carda, M.; Ospina, V.; Munoz, J. A.; Velez, I. D.; Robledo, S. M. European Journal of Medicinal Chemistry 2015, 101, 746. (b) Rahmouni, A.; Souiei, S.; Belkacem, M. A.; Romdhane, A.; Bouajila, J.; Ben Jannet, H. Bioorganic Chemistry 2016, 66, 160. (c) Kazemizadeh, A. R.; Shajari, N.; Shapouri, R.; Adibpour, N.; Teimuri-Mofrad, R. Journal of the Iranian Chemical Society 2016, 13, 1349. 